\title{
Will We be Happier in the Future? Research on the Effect of Covid-19 on Income and Life Satisfaction of the US Citizens
}

\section{Gelecekte Daha mı Mutlu Olacă̆ı?? Covid-19'un Amerikalıların Gelir ve Yaşam Memnuniyetine Etkisi Üzerine Bir Araştırma}

\author{
Hatime KAMİÇELEBİ ${ }^{\mathrm{a}}$ \\ a Assistant Professor, Kırklareli University, Finance and Banking, Kırklareli / TURKEY \\ ORCID: 0000-0002-1028-7135.
}

\section{A K A L E B İ L G İ İ}

Makale Geçmişi:

Başvuru tarihi: 30 Ağustos 2020

Kabul tarihi: 15 Ekim 2020

Anahtar Kelimeler:

Hatalı Tahmin Edilen Öznel İyi Olma

Projeksiyon Ön Yargısı

Yaşam Memnuniyeti

Gelir

Covid-19

\section{A R T ICLE INFO}

\section{Article History:}

Received August 30, 2020

Accepted October 15, 2020

\section{Keywords:}

Mis-Predicted Subjective Well-Being

Projection Bias

Life Satisfaction

Income

Covid-19

\section{ÖZ}

Çalışmada bireylerin gelecekte kendilerinin gelir ve yaşam memnuniyeti (öznel iyi olma) ile ilgili hatalı tahminleri ve bu hatalı tahminlerin sebeplerinden biri olan projeksiyon ön yargısının etkileri açıklanmaktadır. Bireylerin gelecekteki benlikleriyle empati kuramamasıyla ilişkili bilişsel bir ön yargı olan projeksiyon ön yargısı bireyleri gelecekle ilgili tahminlerde bulunurken șu andaki gibi düșünecekleri yanılgısına sokar ve onların gelecekteki yaşam memnuniyetleriyle ilgili hatalı tahminde bulunmasına neden olur. Bireyler gelecekte elde edecekleri yaşam memnuniyetini şu anda tahmin edecekleri zaman gelecekteki duruma adapte olmayı göz önünde bulundurmayıp sistematik hata yapabilirler. Çalıșmamızın amacı bireylerin Covid-19 gibi olumsuz olaylarda yaşam memnuniyetlerinin bu olumsuzluk ortadan kalktığında veya yaşamın olağan bir parçası haline geldiğinde bir başka deyișle bireyler bu duruma adapte olduklarında bu olaydan daha önceki seviyesine geri dönme eğiliminde olduğunu açıklamaktır. Bu çalışmada ABD'de yapılan Gallup Panel ve Gallup Ulusal Sağlık ve İyi Olma İndeksi verilerine dayanarak Amerikalıların Covid-19 süreci başında gelir ve yaşam memnuniyetlerinde azalıs olduğu ortaya çıkarılmıștır. Aynı zamanda bireylerin önümüzdeki beș yıl içindeki yaşam memnuniyeti seviyesinin ne olacağıyla ilgili tahminlerinin altında yatan projeksiyon ön yargısı daha önceki yıllarla kıyaslanarak açıklanmış ve bu tahminlerin hatalı olabileceği literatürle desteklenerek gelir ve yaşam memnuniyetiyle ilgili politikalar belirlenirken bu durumun göz önünde bulundurulması önerisinde bulunulmuştur.

\section{A B S T R A C T}

In this study, individuals' mispredictions regarding their own income and life satisfaction in the future and projection bias effect, as one of the reasons for these mispredictions, are explained. Projection bias, a cognitive bias associated with individuals' inability to empathize with their future selves, renders individuals mistaken that they would think the way they do now while making predictions about the future, and causes them to be mis-predicted about their future life satisfaction. Individuals may make systematic mistakes, by not considering adaptation to the future situation, upon currently predicting their future life satisfaction. Our study aims to explain that the life satisfaction of individuals, upon experiencing certain negative events such as Covid-19, tends to revert to their previous level when such negativity disappears or becomes a normal part of life, meaning, when individuals adapt to this situation. In our study, based on the data of the Gallup Panel and Gallup National Health and Well-Being Index in the USA, it is revealed that the income and life satisfaction of the US citizens decreased as soon as Covid-19 pandemic broke out. At the same time, the projection bias underlying the life satisfaction level of individuals in the next five years is explained by comparing with the previous years, and it is suggested that this situation should be taken into consideration upon determining policies regarding income and life satisfaction by supporting the idea that life satisfaction estimates may be erroneous given the literature.

\footnotetext{
* Sorumlu yazar/Corresponding author.
}

e-posta: hatimekamilcelebi@klu.edu.tr 


\section{EXTENDED ABSTRACT}

$\mathrm{Bu}$ çalışmada Covid-19 ve GALLUP verilerinden yola çıkılarak bireylerin gelecekte kendilerinin elde edecekleri yaşam memnuniyeti (öznel iyi olma) ile ilgili hatalı tahminleri ve bu hatalı tahminlerin sebeplerinden biri olan projeksiyon ön yargısının etkileri açıklanmaktadır. Aynı zamanda Covid-19 nedeniyle Amerikalılar 2008 ekonomik krizine kıyasla gelirleri ve yaşam memnuniyetlerinden daha az memnundur. Özellikle alt gelir grubuna dahil olan Amerikalılar da bu memnuniyetsizlik ciddi boyutlardadır. Bireyler bilișsel bir ön yargı olan projeksiyon ön yargısı nedeniyle gelecekteki benlikleriyle empati kuramadıklarından gelecekle ilgili tahminlerde bulunurken şu andaki gibi düşünecekleri yanılgısıyla düşünmekte ve gelecekteki yaşam memnuniyetleriyle ilgili hatalı tahminlerde bulunmaktadırlar. Bireyler gelecekte elde edecekleri yaşam memnuniyetini şu anda tahmin edecekleri zaman gelecekteki duruma adapte olma, sosyal karşılaştırma yapma vb. etkenleri göz önünde bulundurmayarak tahminlerinde sistematik hata yapabilirler. Çalışmanın amacı bireylerin Covid-19 gibi olumsuz olaylarda yaşam memnuniyetlerinin bu olumsuzluk ortadan kalktı̆̆ında veya yaşamın olağan bir parçası haline geldiğinde bir başka deyişle bireyler bu duruma adapte olduklarında bu olaydan daha önceki seviyesine geri dönme eğiliminde olduğunu açıklamaktır. Bu çalışmayla Covid-19 süreci devam ederken ABD'de yapılan GALLUP Panel ve GALLUP Ulusal Sağlık ve İyi Olma İndeksi (Gallup National Health and Well-Being Index) verilerine dayanarak projeksiyon ön yargısı ve hatalı tahmin edilen öznel iyi oluş kavramlarını açıklayacak sonuçların elde edildiği ortaya çıkarılmıştır. Çünkü Amerikalıların Covid-19 süreci başında ve öncesinde gelir ve yaşam memnuniyetleri karşılaştııılmış, Covid-19 süreci devam ederken yaşam gelir memnuniyeti azalışı olduğu ortaya çıkarılmıştır. Bir başka deyişle 2020 yılından önceki yıllarda Amerikalıların yaşam memnuniyeti ve duygu durumu seviyelerinde istikrarlı bir çizgi söz konusuyken 2020 yılı başından itibaren Covid-19'un etkisiyle birlikte hem yaşam ve gelir memnuniyetlerinde bir azalış meydana gelmiş, hem de sosyal izolasyon, yalnızlık, gelir elde edememe, iş kaybı, parasal kayıplar, yakın gelecekte sağlık ve ekonomik durumları hakkındaki belirsizlikler gibi nedenlerle neşenin azalması, endişe ve streste artış gibi olumsuz yönde değişim olmuştur.

Çalışmada aynı zamanda Amerikalı bireylerin gelecekteki beş yıl içindeki yaşam memnuniyeti seviyesinin ne olacağıyla ilgili tahminlerinin altında yatan projeksiyon ön yargısı daha önceki yıllarla kıyaslanarak açıklanmıştır. Bunun için çalışmada GALLUP'un ölçek olarak kullandığı Cantril Özçıpalama Ölçeği’nde (Cantril Self-Anchoring Striving Scale) sorulan bir soru olan gelecekteki beş yıl içinde kendilerinin yaşam memnuniyeti seviyesinin hangi basamakta olacağ 1 tahminlerine yer verilmiştir. Bu tahminlerin hatalı olabileceği literatürle desteklenmiştir. Konuyla ilgili birçok çalışmada bireylerin gelecekteki benlikleriyle empati kuramaması nedeniyle gelecekle ilgili durumlarını abartma eğiliminde oldukları belirtilmiş̧ir. Amerikalıların yaşam memnuniyetlerinin gelecek beş yıl içinde geçmişte olduğundan daha fazla olacağı beklentisi projeksiyon ön yargısıyla alınan ve hatalı tahmin edilen yaşam memnuniyetine örnek olarak verilebilir. Covid-19'un yarattığı global ekonomik krizin etkilerinin ve sağlık sistemindeki sorunların gelecekteki yıllarda da süreceği göz önünde bulundurulduğunda GALLUP verileriyle de ortaya koyduğumuz gibi bireylerin kendilerini gelecekte daha mutlu düşünmeleri bir illüzyondan ibarettir. Çünkü literatürle de desteklediğimiz gibi bireylerin yaşam memnuniyeti seviyesi zam alma, maaşı yüksek bir işe girme, çocuk sahibi olma, evlilik vb. olumlu olaylarda ve işsizlik, maluliyet vb. gibi olumsuz olaylarda dahi geçmişteki seviyesine dönme eğilimindedir. Şu anda öznel iyi olma hakkında yapılan tahminlerin veya verilen kararların gelecekte yaşanılacak olanla aynı olmaması arasındaki farkın kaynağını açıklayan çalışmalar empati boşluğu ve hedonik adaptasyon üzerine yoğunlaşmışır. Bir başka deyişle hatalı tahmin edilen öznel iyi olmanın altında yatan sebep gelecekteki benliğimizin de şimdiki gibi düşüneceği yanılgısı ve yaşamın getirdiklerine adaptasyonun göz önünde bulundurulmamasıdır.

Bireylerin gelecekle ilgili tahminde bulunurken hedonik adaptasyon faktörünü de hesaba katmaları önemlidir. Yaşam memnuniyetiyle ilgili alınacak iktisadi kararlarda bireylerin gelecekte bekledikleri öznel iyi oluşu gelecekteki hedonik adaptasyonu hesaba katmamalarından ve kendi benlikleriyle empati kuramadıklarından kaynaklanan projeksiyon ön yargısı nedeniyle doğru tahmin edemedikleri hesaba katılarak politika oluşturulurken bu durum göz önünde bulundurulması elzemdir. Davranışlarını şekillendiren bazı faktörlerin farkında olmayan bireylerin, zamanlar arası kararlarda öznel iyi oluşlarını başarıyla en üst düzeye çıkaracak seçimler yapmaları sağlanmalıdır. Aynı zamanda Amerikalı bireylerin ekonomik durum ve yaşam memnuniyetlerindeki farkı Covid-19 öncesi ve Covid-19 süreci boyunca karşılaş̧ırmalı olarak ortaya koyduğumuz bu çalışmaya benzer bir çalışmanın Türkiye için de yapılabilmesi için GALLUP verileri kadar detaylı ve kapsamlı bir panel veya veri setine ihtiyaç duyulmaktadır. Elde edilen sonuçlar bireylerin yaşam ve gelir memnuniyetini artıracak iktisadi politikalar geliştirmek için önemlidir. 


\section{Introduction}

In our study, we explain the erroneous subjective well-being or life satisfaction estimates of individuals regarding their own income and life satisfaction in the future as well as the effects of projection bias that accounts for these mispredictions. Individuals tend to overestimate the extent to which their future tastes and preferences would resemble their current tastes. They are unlikely to predict the change in their current decisions about their future selves (Loewenstein et al., 2003). In other words, they cannot make accurate predictions about future life satisfaction since they fail to consider the duration of time spent, adaptation to that situation and event in the future, economic social comparison, etc. Individuals may make systematic mistakes upon predicting future utility/subjective well-being and therefore, they cannot achieve the maximum utility (Kahneman and Thaler, 2006). Frey and Stutzer (2014, p. 941) also argued that individuals systematically misguided the utility through some of their choices. It is difficult for individuals to make comparisons among the features that vary in prominence over time. In particular, people cannot make an accurate prediction of adaptation. In addition, the degree of adaptation and forecasting differs systematically in terms of goods and activities (Fehr and Camerer, 2007, p. 420).

Many people predict that their life satisfaction would increase as they earn more income. Because they focus on this illusion, they make the mistake of exaggerating the boost in happiness, but it is known that the long-term effect of income decreases since they adapt to daily life (Kahneman et al., 2006). For instance, they may be willing to sacrifice the time spent for socializing upon considering the long duration of time they would spend in traffic for commuting due to their focus on income growth (Stutzer and Frey, 2008). It has been revealed that individuals fail to make accurate predictions of future life satisfaction or subjective well-being due to certain biases. Because it has been understood that people adapt to their future situations due to the hedonic adaptation effect and the line of life satisfaction does not change much (Kahneman, 1999; Schkade and Kahneman, 1998). Therefore, projection bias, which is one of the reasons underlying the individuals' misprediction of their future subjective well-being/life satisfaction, is emphasized. Gallup asked the participant US citizens questions about income and life satisfaction before and after the Covid-19 breakout. Among these questions, life satisfaction predictions for the future as well as their current satisfaction also take place.

In our study, it is emphasized that income and life satisfaction evaluations are mispredicted due to the projection bias in the USA over the years. In the second part of our study, the projection bias is explained through the examples of individuals' erroneous life satisfaction predictions. In the third part, the concept of mis-predicted well-being and hedonic adaptation is introduced with examples. In the fourth part, with the obtained data from Gallup, the income and life satisfaction of the US citizens before and after the Covid-19 breakout, and their satisfaction for the future are evaluated. Since there is no study that explains mis-predicted subjective wellbeing using Covid-19 data, our study is an original study that would form the basis for this domain.

\section{Projection Bias and Empathy Gap}

Projection bias is the tendency of people to assume that what they like and dislike in the future would resemble what they like and dislike at the moment. However, individuals may also enjoy and be content with different things in the future. Therefore, in behavioral economics, erroneous beliefs about the future are explained through projection bias (Erta et al., 2013, p. 6). In other words, it is a mindset that connects how people feel today and what they expect to feel in the future. Such bias allows us to make predictions about our future selves. By reflecting our present feelings to the future, we expect to feel in the future as it is today. This bias is directly 
associated with the individuals' inability to accurately estimate future utilities. Loewenstein et al. (2003) argued that such bias occurs since it forms an anchor point that serves as the basis for our current emotional states, thoughts, feelings, and behaviors.

The decisions we make now and our perceptions of the normality of these actions are made according to the previously set anchor point. For example, studies conducted in China indicated that although air pollution is harmful in the long-run, subjective well-being assessments (Chena et al., 2019) and health insurance purchasing or cancellation decisions are made based on daily air pollution values. It was revealed that the increase in daily air pollution induced a $7.2 \%$ increase in the number of insurances and this was linked to projection bias (Chang et al., 2018). As another example, the bias arises when we have the wrong idea that our future hunger would be as great as it is now during shopping. Normally, assessments on the usefulness and desirability of a particular item now and in the future may vary. Experiencing projection bias is a prediction of how much an item or event will be valued in the future. In one study, athletes were asked to imagine what the mountaineers who were lost in the barren mountains without water and food would fell and decide on whether thirst or hunger would be worse for them. Before entering the gym, 61 percent of the athletes stated that thirst would be a more disturbing feeling for mountaineers and themselves, whereas 92 percent of them stated that they would find the thirst much more disturbing after leaving the gym. Here, it is understood that the athletes reflected their thirst for the mountaineers. It was revealed that they could not fully predict this feeling about themselves and the mountaineers and could not accurately predict the future utility (Van Boven and Loewenstein, 2003).

According to the findings obtained about projection bias, it was found that when individuals asked to predict their future actions, they tend not to empathize with their future selves. This bias leads people to overestimate reference-dependent goods and exaggerate the endowment effect (Loewenstein et al., 2003). According to a study, it was determined that people who do not currently own an object underrate how much those who have the object value their objects, and even underestimated the value they would have given the object if they had the object themselves (Van Boven et al., 2000; Loewenstein et al., 2003). These predictions reveal statistically both about property owners' assessment and people's biased estimates of how valuable the trophy would be to them if they had a trophy.

Van Boven et al. (2000) designed an experiment to reveal projection bias. Coffee cups were given to each one of a certain student group in the experiment, but not to the other group. The subjects with and without coffee cups were asked to determine the selling price for the cup. Those with the cups set a higher selling price (\$6.37) than those without the cups $(\$ 1.85)$. Those without the cups were asked to estimate how much they would pay to purchase these cups, and those without the cups were asked to estimate how much they would charge to sell them. The average estimate of the ones having cups is $\$ 3.93$, which is lower than the selling price they set in the first experiment, but higher than either two prices reported for the purchase. The average price for buyers without cups is $\$ 4.39$, which is higher than their average purchase price, but lower than the average selling price. Here, the pricing difference between the ones with and without cups is explained by both projection bias and empathy gap. Loewenstein and Adler (1995) also proved in another experiment that estimated selling prices are significantly lower than actual selling prices, being consistent with the projection bias. Therefore, the empathy gap has emerged as a result of people's misconceptions about their next predictions and their inability to empathize with their own selves and their inability to put themselves in the other's positions. It is as if the misconception that people's tastes and preferences in the future would be the same as they are today. Individuals' desire to satisfy their present desires and emotional states often invalidate long-term goals that would satisfy their future selves (Loewenstein and Schkade, 1999; Loewenstein et al., 2003). 


\section{Mis-predicted Subjective Well-Being and Hedonic Adaptation}

Subjective well-being appears as a broader concept that includes experienced happiness and evaluation of life (Kahneman and Deaton, 2010, p. 16489). In the subjective approach of utility, the happiness expressed by the fact that individuals have a certain opinion about happiness and a good life indicates the well-being of people. Subjective well-being is a crucial factor to directly measure the cognitive and emotional effects of individuals' entire lives as well as special parts of life (Diener, 1984; Myers and Diener, 1995). Veenhoven (1984, p. 17-25) stated that life satisfaction, happiness, and subjective well-being are used interchangeably. Veenhoven favored using the concept of life satisfaction instead of subjective well-being; since life, satisfaction includes a general evaluation of life rather than momentary emotions. In this context, happiness includes all aspects of life (work, family, social life, consumption opportunities, health, etc. all life spheres) and is a general judgment consisting of two criteria. One of them is the 'hedonistic level' (intuitive evaluations) and the other is 'satisfaction', which includes cognitive transformations based on the individual's desires and achievements (Veenhoven, 2004). Although individuals' evaluation of the events in their lives and their hedonistic levels may change over time, it is still possible that their emotions determined by temperament and daily life conditions would revert to an average borderline. Although the emotions are constantly changing, it is possible that the subjective well-being level of individuals would become stable in the long run. Similarly, when the living conditions of the individual change significantly, the life satisfaction of the individual may also change, however, the stability in life satisfaction gains consistency over time and persists to some extent (Diener, 2009, p. 29).

There are discrepancies between the two concepts of well-being. Emotional well-being (hedonistic well-being or experienced happiness) indicates the emotional quality that the individual experiences every day and it is associated with the intensity and frequency of experiences such as compassion, anger, sadness, joy, and anxiety which determine whether or not he/she is satisfied with their life. The concept of life evaluation is an individual's thoughts regarding their own life (Kahneman and Deaton, 2010, p. 16489).

There is persuasive empirical evidence suggesting that individuals are not good at predicting their future satisfaction/utilities (Loewenstein and Adler, 1995). Research on effective prediction tends to exaggerate their reactions in those events, especially since people experience other routine daily life events of which they are not currently conscious, such as their team becoming champions and finding professional occupations simultaneously with routine events. People often have biased predictions about the density and duration of their emotions since people are able to adapt more and more easily than they anticipate (Frey and Stutzer, 2014). The concept of adaptation, which is discussed here with life satisfaction, is any process, movement, or mechanism that mitigates the effects of a repetitive situation (pleasure, motivational, perceptual, physiological, etc.) (Frederick and Loewenstein, 1999). Following such adaptation, people's happiness reaches a level similar to of those before these events. This situation is called hedonic adaptation (Brickman and Campbell, 1971). In the hedonic cycle, the individual can evaluate their current situation, and also make mispredictions about their future situation. It has been found that individuals with incomes have enough imagination about themselves about their own income in the future as they do now. These results also explain that individuals have their own positive and negative emotional domains and, even if we move away from this area in the face of sad or pleasing life events, they revert over time (Van Praag, 1977; Van Praag and Van der Sar, 1988).

While individuals make predictions about their future, they do not perceive that they will adapt to the future situation and that the social comparisons they make about their economic conditions would change commensurate with the actual conditions (Easterlin, 2003). Even the 
negative effects of life events such as grief, disability, and chronic illness on subjective wellbeing tend to revert to a degree (Frederick and Loewenstein, 1999; Oswald and Powdthavee, 2008). People who are unemployed for a long time cannot fully revert to their life satisfaction level prior to unemployment (Clark et al., 2008), but following important events such as having children, death of spouse and marriage, people revert to their previous life satisfaction levels from such situation, in other words, they adapt to the situation in which they are (Kamilçelebi and Veenhoven, 2016; Clark et al., 2008; Stutzer and Frey, 2006, Luhman et al. 2012). People, in general, adapt quickly to situations of happiness or grief. After experiencing a good event such as a salary raise and winning the lottery, or after experiencing a bad event such as loss and illness, people emotionally adapt to such situations (Diener et al., 2006). So, it is quite likely that each individual has an inner baseline for some level of happiness or sadness. Mis-predicting future emotions may also stem from underestimate their future desires (Bernheim and Rangel, 2016, p. 57; Loewenstein et al., 2003).

Odermatt and Stutzer (2015) examined the extent to which people predicted their future well-being accurately after encountering major life events. Based on panel data, people's actual assessments made after five years later were compared with estimates of life satisfaction reported at the first interview following a major life event. It was made after individuals' experiences of widowhood, unemployment, disability, marriage, separation, or divorce and found systematic prediction errors following the first four of these events. This result partly stemmed from unpredictable adaptation. Loewenstein et al. (2003) established a theoretical model on intertemporal decision-making and they proved with experiments that individuals predicted their future utilities incorrectly due to projection bias.

It has been the subject of many studies in which the future utility or subjective wellbeing cannot be accurately predicted (Kahneman et al., 2007; Kahneman and Thaler, 2006). In a study, which explained that future life satisfaction could not be estimated accurately, a group was asked questions about life satisfaction on two distinct dates. The first survey was conducted before these people received a salary raise and they were asked whether their happiness would increase if they received a raise higher than the inflation rate. With this survey, life satisfaction predictions about the future were obtained. In the second survey questionnaire, the same participants were asked about their life satisfaction, and both results were compared. Accordingly, it was revealed that the life satisfaction levels of those who expected a salary raise would have not increased their happiness after receiving a raise. Despite this, no significant relationship was found between life satisfaction and post- salary raise of the academicians who expected the salary raise to increase their happiness. At this point, the difference between the life satisfaction predictions that people will achieve in the future and the actual predictions revealed that people's predictions about the future may be incorrect (Kamilçelebi, 2018a; Kamilçelebi, 2018b; Kamilçelebi, 2019, p. 94). Although income increase was expected to boost subjective well-being, it might have had little effect on subjective well-being due to hedonic adaptation (Frederick and Loewenstein, 1999).

The following result was obtained from the German Socioeconomic Panel survey conducted over the period 1984-2005, which explained the mis-predicted subjective well-being that might have arisen in decisions taken with projection bias. When individuals learn that they will receive fifty percent more salary in their current job before starting to work, the level of satisfaction of individuals increases. Despite this, the satisfaction provided by the income decreases in later periods, and after a while, it reverts to almost its previous level (Frey and Stutzer, 2014, p. 943). This situation can be explained by hedonic adaptation, individuals adapt to the opportunities provided by income following a certain period. 


\section{Scope and Findings of the Research}

The research data are obtained from GALLUP. Because of the pandemic, the life satisfaction and financial satisfaction of individuals in the USA, as well as their level of anxiety, concern, and cheerfulness are compared with previous years. Moreover, the questions of the Cantril Self Anchoring Striving Scale used by GALLUP were utilized regarding life satisfaction predictions after five years. Based on this, the individuals' prediction of their future life satisfaction (subjective well-being) that form the basis of our research is explained by comparing it with previous years.

It is revealed that the US citizens' satisfaction with their financial situation at the beginning of 2020 has changed compared to previous years. While the satisfaction of those who report that they are mostly or completely satisfied with their current income status has increased in 2020, the satisfaction of those who are not satisfied with their income before 2020 has decreased (NORC).

Table 1: American's Emotions During Covid-19 by Subgroup

\begin{tabular}{|c|c|c|c|c|}
\hline \multicolumn{5}{|c|}{ Percentages who experienced the following feelings "during a lot of the days yesterday" } \\
\hline & Happiness \% & Worry \% & Boredom \% & Loneliness \% \\
\hline \multicolumn{5}{|l|}{$\begin{array}{l}\text { Annual household } \\
\text { income }\end{array}$} \\
\hline$<\$ 36.000$ & 56 & 58 & 49 & 38 \\
\hline$\$ 36.000-<\$ 90.000$ & 74 & 44 & 41 & 23 \\
\hline$\$ 90.000+$ & 75 & 48 & 39 & 19 \\
\hline \multicolumn{5}{|l|}{ Marital Status } \\
\hline Married & 77 & 45 & 39 & 17 \\
\hline Single/Never married & 61 & 50 & 46 & 36 \\
\hline Divorced & 62 & 50 & 39 & 35 \\
\hline Widowed & 76 & 38 & 45 & 26 \\
\hline \multicolumn{5}{|l|}{ Gender } \\
\hline Men & 73 & 44 & 43 & 20 \\
\hline Women & 71 & 51 & 40 & 27 \\
\hline
\end{tabular}

Source: GALLUP PANEL, April 27-10 May 2020, https://news.gallup.com/poll/311135/adults-reportless-worry-happiness.aspx

(The results of this GALLUP survey are based on self-administered web surveys with a random sample of 8,712 US adults aged 18 and over who are the members of the GALLUP Panel over the period from 27 April to 10 May 2020. 95\% confidence level. The margins of error are higher for subgroups.)

In Table 1, the US citizens who have participated in the survey are asked about their emotions the previous day and the differences in emotions about the Covid-19 pandemic in 
terms of the variables of household income, marital status, and gender are presented. For example, the US adults with an annual household income of less than $\$ 36,000$, which is the lower-income group, have dramatically higher daily feelings of anxiety, boredom, and loneliness than high-income groups. Upon comparing the lower income group with the middleand upper-income groups, most of the participants are much less likely to claim that they were happy the previous day. It is found that the married and widowed US citizens feel happier and less anxious, whereas those who are single or divorced feel lonelier. Women are more likely than men to feel anxious and lonely.

GALLUP evaluates Americans according to the Self Anchoring Striving Scale, which was designed by Cantril (1965), using the digit scale ranging from 0 to 10. According to this scale, people are classified as 'thriving', 'struggling' and 'suffering' depending on how they rate their current and future lives. Those who evaluate their current life satisfaction as 7 or higher and their life satisfaction as 8 or higher in five years are classified as 'thriving'.

Table 2: Life Evaluation (\% Thriving), Current Life Satisfaction, and Anticipated Life Satisfaction in 5 Years, Trended, by Age

$\begin{array}{cccc}30 \text { Sep- 14 Oct } & \begin{array}{c}\text { 21 Mar-5 Apr } \\ 2019\end{array} & \begin{array}{c}\text { 20-26 Apr } \\ 2020\end{array} & \begin{array}{c}\text { Change } \\ \text { (pts.) }\end{array} \\ \% & \% & \% & \end{array}$

Thriving

$18-44$

$45-64$

$65+$

All Adults

Current Life Satisfaction (7-10) \%

$18-44$

$45-64$

$65+$

All Adults

Anticipated Life Satisfaction in 5 Yrs. (8-10) \%

$18-44$

45-64

$65+$

All Adults

*Statistically significantly different $(\mathrm{p}<.05)$

$95 \%$ confidence level
55.8

57.3

51.1

55.3

60.6

70.6

78.6

67.7

71.6

65.5

53.7

65.5
45.9

$-9.9 *$

53.0

$-4.3 *$

$-3.4^{*}$

$-6.5^{*}$

48.8

50.3

$-10.3 *$

61.7

$-8.9$

68.3

$-10.3 *$

58.2

56.9

$-10.8 *$

71.5

$-0.1$

69.4

$+3.9 *$

58.9

$+5.2 *$

68.0

68.9

$+3.4^{*}$ 
Source: GALLUP, 30 September-14 October 2019 and 21 March - 5 April 2020, https://news.gallup.com/poll/308276/life-ratings-plummet-year-low.aspx; $\quad 20-26$ April 2020, https://news.gallup.com/poll/310250/worry-stress-fuel-record-drop-life-satisfaction.aspx

(Note: The results recorded over the period between 21 March- 26 April 2020 are obtained from the interviews held with 20,006 participants randomly selected from the GALLUP Panel, consisting of approximately 80,000 adults in all 50 US states and Columbia region. The results obtained over the period between 30 September - 14 October 2019 are based on the responses of 33,451 panel participants.)

Table 2 shows that the probability of being successful in life evaluation is the highest among young and middle-aged people and it decreases with age following a certain point. The decline in the percentage of successful individuals is significantly greater among the adults aged 18-44 than of older age groups and has dropped by about 10 percentage points to $45.9 \%$ for young adults in the most recent sample. This is largely due to the decline in current life satisfaction ratings and the lack of improvement in predicted life satisfaction for this group within five years. Among older individuals, predicted future life satisfaction increases significantly compared to the period of September-October 2019, helping offset the decline in current life satisfaction, results in a smaller decrease in success.

Over the period between September-October 2019 and the end of April 2020, the percentage of those who rate their current lives as ' 7 ' or higher drops to $56 \%$, along with a similar decrease (10.8 points) across all age groups. On the contrary, the ratings of predicted future lives are slightly improved. In the question of life satisfaction, the participants are asked to rate their predictions within five years according to the level of this scale ranging from 1 to 10. Accordingly, the predicted level of life satisfaction of all adults within five years (between 8-10) is higher (45-65+ years of age) compared to September-October 2019 evaluations, and lower (18-44 years of age) compared to March-April 2020 evaluations.

The life satisfaction ratings of all adults within five years increase by 3.4 points to $68.9 \%$ (between 8-10) compared to the October 2019 evaluations. At this point, it is explained that the US citizens have unusually low satisfaction with their current lives, and they stretch further an overall optimism regarding the future. This illusion in our predictions about the future serves as a projection bias and is due to the inability to fully predict future life satisfaction. With the Covid-19 outbreak, this illusion has updated itself again, and these new results have widened the gap between what the US citizens predict their life satisfaction to be five years from now compared to how they rate their current lives.

Daily Emotional Experiences of U.S. Adults, Trended (January 2018-April 2020)

Did you experience each of the following a lot of the day yesterday?

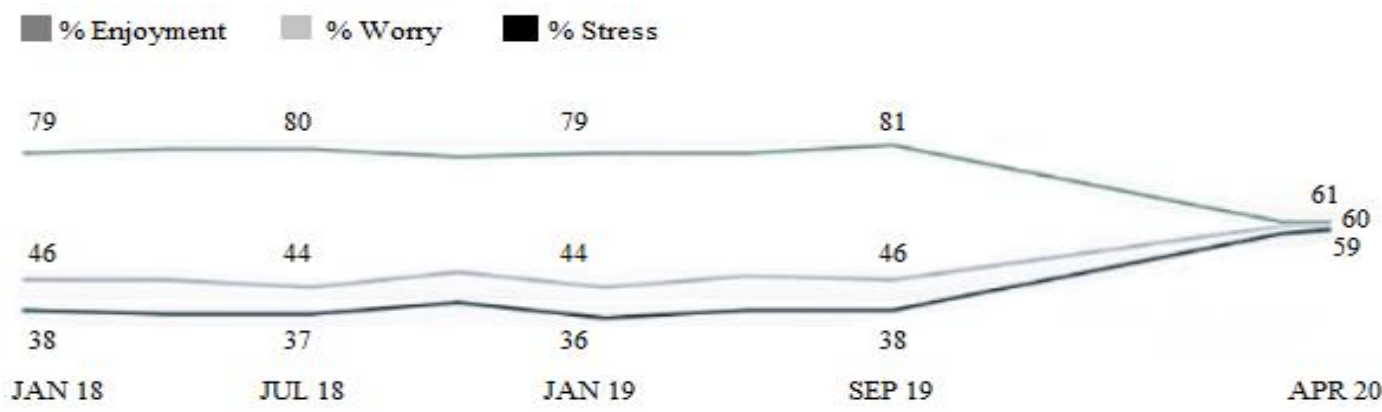

Figure 1: Daily Emotional Experiences of U.S. Adults, Trended (January 2018-April 2020) 
Source: GALLUP, Data from January 2018 to August 2019 are based on the Gallup National Health and Well-Being Index; 6-20 March and 21 March - 5 April 2020 are based the Gallup Panel, https://news.gallup.com/poll/308276/life-ratings-plummet-year-low.aspx

It also applies to situations in which individuals experience significant stress and anxiety on any given day. As can be seen in Figure 1, the stress and anxiety percentages of the US citizens have been quite stable throughout the years and exhibit merely a slight change over time. Nonetheless, the percentages of the US adults who experience significant stress and anxiety daily over the period between March-April 2020 increase unprecedentedly compared to the period between July-August 2019. Stress levels increase by 14 points to $60 \%$, whereas anxiety levels increase by 21 points to $59 \%$. The percentage of those who enjoyed significant daily enjoyment drops by 20 percentage points to $61 \%$ during this period. In practical terms, approximately 53 million adults experience more of the anxiety they do on any given day over the period between March-early April 2020 compared to the period between July-August 2019.

Table 3: U.S. Change in Significant Daily Enjoyment, Worry and Stress

\begin{tabular}{l|c|c|c}
\hline $\begin{array}{l}\text { Change, in percentage points, between the two- } \\
\text { time period noted }\end{array}$ & +1.1 & +5.0 & +3.3 \\
\hline October 2008 vs. January 2008 & -19.7 & +20.8 & +14.0 \\
\hline 21 March-7 April 2020 vs. July-August 2019 &
\end{tabular}

Source: GALLUP, https://news.gallup.com/poll/308276/life-ratings-plummet-year-low.aspx

Notes: 2008 and 2009 data are based on the Gallup National Health and Well-Being Index; 2020 data are based on the Gallup Panel. Over the period between March 21-April 5, 2020; the GALLUP survey is based on a sample of 20,006 adults aged 18 and over residing in all 50 US states and the District of Columbia.

(The margin of sampling error is approximately +0.9 points at $95 \%$ confidence level.)

Table 3 indicates that the magnitude of the anxiety and anxiety caused by the coronavirus is greater than that observed in the 2008 economic crisis. It takes about two years for the stress and anxiety levels to drop to early 2008 levels. Upon comparing the period between 21 March - 5 April 2020 with the period between July-August, 2019; it is seen that the anxiety and stress caused by the coronavirus have significantly exceeded the anxiety and stress that occurred in 2008. It is determined that within the specified months of 2019 and 2020 , daily entertainment decreases by approximately 20 points, anxiety increases approximately by 20 points, and stress increases approximately by 14 points.

\section{Conclusion and Evaluation}

According to the GALLUP data of US adults, it is understood that the decline in life satisfaction caused by Covid-19 exceeds the levels measured in the 2008 crisis when combined with the damage inflicted on the economy. Before the Covid-19 outbreak, serious discrepancies are found between what people experienced on any given day regarding income and life satisfaction and their experiences throughout this process. Several life-changing factors can be explained by the decrease in cheerfulness in the daily emotions of individuals, an increase in anxiety and stress, a decrease in income and life satisfaction, and uncertainties about their health and economic conditions within the near future. It is revealed that this situation affects especially the lower income group even more. Social isolation, job loss, loneliness, financial loss, etc. situations also reduce the quality of life.

The life satisfaction levels of people tend to revert to their previous levels when they run into several adverse events that are not in their routine, such as Covid-19, when this negative situation disappears or becomes a normal part of life, meanings, when they adapt to it. However, 
cognitive biases such as projection bias regarding individuals' future selves cause them to make mispredictions about their future life satisfaction. As we demonstrate using the GALLUP data, the prevailing opinion is that individuals would be happier in the future than they are now or were before. The fact that people usually expect that they will be more satisfied with their future lives is an illusion explained by projection bias, based on their inability to empathize with their future selves. It is important for individuals to consider the hedonic adaptation factor upon making predictions. This situation should be taken into account upon implementing a policy since individuals cannot accurately predict the subjective well-being they expect in the future due to projection bias and the fact that they fail to consider the future hedonic adaptation and cannot empathize with their own selves in economic decisions to be made regarding life satisfaction. Individuals who are unaware of some of the factors that shape their behavior should be ensured to make choices that would successfully maximize their subjective well-being in intertemporal decisions. A study similar to this one which would yield up the economic situation and life satisfaction of the people in the face of Covid-19 breakout is necessary, but no such dataset is available yet.

\section{References}

Bernheim, B. D. \& Rangel, A. (2016). Davranışsal kamu ekonomisi: Standart olmayan karar mercileri ile refah ve politika analizi. In Hatime Kamilçelebi (Ed), Davranışsal İktisat ve Davranışsal İktisadın Uygulamaları. Ankara: Nobel Akademik Yayınları, 7-81.

Brickman, P. \& Campbell, D. T. (1971). Hedonic relativism and planning the good society. In M. H.Appley (Ed), Adaptation level theory: A symposium. New York: Academic Press, 287-302.

Cantril, H. (1965). The pattern of human concern. New Jersey: Rutgers University Press.

Chang, T. Y., Huang, W. \& Wang, Y. (2018). Something in the air: Projection bias and the demand for health insurance. The Review of Economic Studies, 85(3), 1609-1634. https://doi.org/10.1093/restud/rdy016

Chena, S., Qin, P., Tan-Soo, J. \& Wei, C. (2019). Recency and projection biases in air quality valuation by Chinese residents. Science of The Total Environment, 648, 618-630. https://doi.org/10.1016/j.scitotenv.2018.08.153

Clark, A. E., Diener, E., Georgellis, Y. \& Lucas, R. (2008). Lags and leads in life satisfaction: A test of the baseline hypothesis. Economic Journal, 118(529): F222- F243. https://doi.org/10.1111/j.1468-0297.2008.02150.x

Diener, E. (1984). Subjective well-being. Psychological Bulletin, 95(3), 542-575.

Diener, E., Lucas, R. E. \& Scollon, C. N. (2006). Beyond the hedonic treadmill: Revising the adaptation theory of well-being. American Psychologist, 61(4), 305-314. https://doi.org/10.1037/0003-066X.61.4.305

Diener, E. (2009). Assessing subjective well-being: Progress and opportunities. Assessing wellbeing the collected works of Ed Diener, Ed Diener (Ed), Social Indicators Research Series, 39, 103-157.

Easterlin, R. A. (2003). Building a better theory of well-being. In Luigino Bruni and Pier Luigi Porta (Eds), Economics and happiness: Framing the analysis. New York: Oxford University Press, 29-64.

Erta, K., Iscenko, Z., Hunt, S. \& Brambley, W. (2013). Applying behavioural economics at the financial conduct authority. London: Financial Conduct Authority. 
Fehr, E. \& Camerer, C. F. (2007). Social neuroeconomics: The neural circuitry of social preferences. Trends in Cognitive Sciences, 11(10), 419-427. doi: 10.1016/j.tics.2007.09.002

Frederick, S. \& Loewenstein, G. (1999). Hedonic adaptation. In D. Kahneman, E. Diener, \& N. Schwarz (Eds), Well-being: The foundations of hedonic psychology, Russell Sage Foundation, 302-329.

Frey, B. \& Stutzer, A. (2014). Economic consequences of mispredicting utility. Journal of Happiness Studies, 15(4), 937-956. doi: 10.1007/s10902-013-9457-4

GALLUP, April 27-10 May 102020 https://news.gallup.com/poll/311135/adults-report-lessworry-happiness.aspx

GALLUP, 20-26 April 2020 https://news.gallup.com/poll/310250/worry-stress-fuel-recorddrop-life-satisfaction.aspx

GALLUP, 30 September-14 October 2019 and 21 March - 5 April 2020 https://news.gallup.com/poll/308276/life-ratings-plummet-year-low.aspx

Kahneman, D. (1999). Objective happiness. In D. Kahneman, E. Diener, \& N. Schwarz (Eds), Well-being: The foundations of hedonic psychology, Russell Sage Foundation, 3-25.

Kahneman, D. \& Deaton, A. (2010). High income improves evaluation of life but not emotional well-being. Psychological and Cognitive Science, 107(38), 16489-16493. https://doi.org/10.1073/pnas.1011492107

Kahneman, D. \& Thaler R. H. (2006). Anomalies: Utility maximization and experienced utility. Journal of Economic Perspectives, 20(1), 221-234. doi: 10.1257/089533006776526076

Kahneman, D., Wakker, P. P. \& Sarin, R. (1997). Back to Bentham? Explorations of experienced utility. Quarterly Journal of Economics 112(2), 375-405. https://doi.org/10.1162/003355397555235

Kahneman, D., Krueger, A. B., Schkade, D., Schwarz, N. \& Stone, A. A. (2006). Would you be happier if you were richer? A focusing illusion. Science. 312(5782), 1908-1910. doi:10.1126/science. 1129688

Kamilçelebi, H. \& Veenhoven, R. (2016). The difference between expected and experienced utility: Findings from some studies on having children. The Journal of Academic Social Science Studies, 50, 343-354. http://dx.doi.org/10.9761/JASSS3591

Kamilçelebi, H. (2018a). Beklenen fayda ve deneyimlenen fayda: Gelir artışı üzerine bir araştırma. Bursa: Ekin Yayınevi.

Kamilçelebi, H. (2018b). The difference between expected and experienced utility: A case study on a salary increase. Saarbrücken: Lambert Academic Publishing.

Kamilçelebi, H. (2019). Davranışsal iktisat. London: IJOPEC Publication.

Loewenstein, G. \& Adler, D. (1995). A bias in the prediction of tastes. Economic Journal, 105(431), 929-937. doi: 10.2307/2235159

Loewenstein, G., O’Donoghue, T. \& Rabin, M. (2003). Projection bias in predicting future utility. Quarterly Journal of Economics, 118(4), 1209-1248. https://doi.org/10.1162/003355303322552784

Loewenstein, G. \& Schkade, D. (1999). Wouldn't it be nice? Predicting future feelings. In Daniel Kahneman, Ed Diener and Norbert Schwarz (Eds), Well-Being: The Foundation of Hedonic Psychology. New York: Russell Sage Foundation, 85-105. 
Luhman, M., Hofmann, W., Eid, M. \& Lucas, R. E. (2012). Subjective well-being and adaptation to life events: A meta-analysis. Journal of Personality and Social Psychology, 102(3), 592-615. doi: 10.1037/a0025948

Myers, D. G. \& Diener, E. (1995). Who is happy?. Psychological Science, 6(1), 10-19.

NORC, https://www.norc.org/Pages/default.aspx

Odermatt, R. \& Stutzer, A. (2015). (Mis-)predicted subjective well-being following life events. IZA Discussion Papers 9252, 1-42.

Oswald, A. \& Powdthavee, N. (2008). Does happiness adapt? A longitudinal study of disability with implications for economists and judges. Journal of Public Economics, 92(5-6), 1061-1077. https://doi.org/10.1016/j.jpubeco.2008.01.002

Schkade, D. A. \& Kahneman, D. (1998). Does living in California make people happy? A focusing illusion in judgments of life satisfaction. Psychological Science, 9(5), 340 346. https://doi.org/10.1111/1467-9280.00066

Stutzer, A. \& Frey, B., (2008). 'Stress that doesn't pay: The commuting paradox. The Scandinavian Journal of Economics, 110(2), 339-366. https://doi.org/10.1111/j.14679442.2008.00542.x

Stutzer, A. \& Frey, B. S. (2006). Does marriage make people happy, or do happy people get married? Journal of Socio-Economics, 35(2), 326-347. https://doi.org/10.1016/j.socec.2005.11.043

Van Boven, L. \& Loewenstein, G. (2003). Social projection of transient drive states. Personality and Social Psychology Bulletin, 29(9), 1159-1168. doi: $10.1177 / 0146167203254597$

Van Boven, L., Dunning D. \& Loewenstein, G. (2000). Egocentric empathy gaps between owners and buyers: Misperceptions of the endowment effect. Journal of Personality and Social Psychology, 79(1), 66-76.

Van Praag, B. M. S. \& Van der Sar, N. L. (1988). Household cost functions and equivalence scale. Journal of Human Resources, 23(2), 193-210.

Van Praag, B. (1977). The perception of welfare inequality, European Economic Review, 10(2), 189-207.

Veenhoven, R. (2004). Happy life years: Measures of gross national happiness, Proceedings of the First International Conference on Operationalization of Gross National Happiness, 294-296, (http://archiv.ub.uni-heidelberg.de/savifadok/1210/1/Happy_Life_Years.pdf).

Veenhoven, R. (1984). Condition of happiness. D. Reidel Publishing Company. 